\title{
Study on Family Rules in the Ming and Qing Dynasties
}

\author{
Di Wang \\ The Law School of China University of Political Science and Law, Beijing, China \\ Email: guicaitang@163.com \\ Received 4 October 2014; revised 3 November 2014; accepted 9 November 2014 \\ Copyright (C) 2014 by author and Scientific Research Publishing Inc. \\ This work is licensed under the Creative Commons Attribution International License (CC BY). \\ http://creativecommons.org/licenses/by/4.0/

C. (†) Open Access

\begin{abstract}
In the Ming and Qing Dynasties, the state laid emphasis on the village society control, encouraging families at different places to set norms restraining family members in genealogical record and vesting family elders with power to decide and enforce these norms. It was in this period that the family rules achieved rapid development, having increasingly mature content and form and general support from authorities; therefore, the Ming and Qing Dynasties became a typical time for the development of ancient family rules.
\end{abstract}

\section{Keywords}

Family Rules, The Ming and Qing Dynasties, Family Order, Clan Regulations

\section{Introduction}

The family system in China has a long history, originating from the late primitive society and going through four different forms of succession: the patriarchy in the late primitive society, the patriarchal clan system in the Yin and Zhou Dynasties, the aristocratic clan system from the Han Dynasty to Tang Dynasty and the ancestral hall clan system after the Song Dynasty until the Ming and Qing Dynasties, where the family rules flourished indeed, with increasingly mature content and form and general support from authorities. In the early Ming Dynasty, Taizu Emperor Zhu Yuanzhang spoke highly of Zheng Family in Pujiang and Song Lian who helped to finish the renowned Norms of Zheng Family. Since then, a large number of dignitaries and celebrities had followed and established family rules which were enforced inside the family. With ancestral hall as center and ancestor worship as tie, the family members were closely linked together, which formed the ancestral hall clan system after the Song Dynasty. 


\section{Basic Contents of the Family Rules in the Ming and Qing Dynasties}

The family system in the Ming and Qing Dynasties was most characterized by: enlarged scope of kin binding, deepened relationship with regional society, and numerous clans with power penetrated into every corner of rural society becoming the power system second only to the regime. The clan power was formed in the late Ming Dynasty and further strengthened in the Qing Dynasty, finally matching the feudal regime and playing the role of grass-roots political authority. The clan power in the Ming and Qing Dynasties was composed of clan leader, household leader, ancestral hall, clan farmland and genealogy, of which the ancestral hall, genealogy and clan farmland were the basic features. For the purpose of legalization of his own power and better control of clan members, the ruler set the family law and realized the legalization and systematization of clan power [1]. Therefore, for clan members, the clan leader became the "judge" and the clan rules became the "national law". By virtue of the authority of clan leader and other elders as well as family rules, the clan conducted effective coordination and control over frictions and disputes inside the clan group so as to realize the behavior restriction on family members. The basic contents of the family rules in this period include:

1) It was compulsory for every clan member to respect ancestors and defend hierarchy

“Ancestor worship” is a "ritual activity" which was of great importance in spiritual aspect in ancient times. Harriet Zurndorfer, a Netherlandish scholar, believes that the clan in China regards itself as a historical entity rather than a realistic entity and every clan member values the mission of continuing the family line above his own real life. On the other hand, unlike people in Western countries having religion as spirit support, farmers in ancient China were mentally poor. While ancestor worship provides the descendants of the same surname with natural spiritual dependence; at the same time, the activity "ancestor worship” itself is able to meet the farmers' needs for cultural life [2]. The clan regulations in the Ming and Qing Dynasties not only specified the compulsory execution of ancestor worship ceremony but also made detailed restrictions and provisions regarding participants and procedures: the ancestor worship shall be hosted by clan leader or patriarch and only this-worldly descendants (mainly referring to the male adults in principal family) of the worshiped ancestor are eligible to participate in the ceremony. The men of different surname into the clan, the men of the same surname out of the clan, women and male minors are not eligible for the ceremony. The worship ceremony has certain etiquettes, which are stated differently from different clans. In the ceremony process, the clan organization would pay substantial amounts of public funds to buy ritual food for ancestors and then give it to clan members in the name of ancestors. The sacrificial offerings obtained by clan members are called "Zuo". The clan members who violate the family rules would be temporarily or permanently deprived of the right to receive "Zuo" after worship ceremony, which is called "Removal of Zuo".

The Chinese etiquette-governing thought is based on the manners of "being harmonious and respectful". The ethic relation in ancient times was always the hierarchy deciding superiors and inferiors by blood, and internal family was no exception: certain criteria would be used to decide the close and distant, the noble and lowly, thereby ensuring people at different classes to enjoy different rights and assume different obligations.. For the status classification, triple standard "blood, politics and economics" is adopted. First, blood is the criterion to determine presence of the clan identity which can be achieved only through birth or marriage. Second, the double standard "economics and politics" is used to determine the ranking of clan pyramid. In the Ming and Qing Dynasties, the social status of a family was usually measured according to the number of this family members who had succeeded in the imperial examination and entered the official career as well as their post of official rank. While through the officials in the clan, the family group would strengthen relations with the state power and also obtain social and economic power or privileges [3]. The clan leader is endowed with extensive clan power. The clan system is established based on the patriarchy principle. The clan leader is seen as Zongzi who is the Master of the clan. The clan power was formed in the Ming Dynasty and further strengthened in the Qing Dynasty. The power of clan leader includes: the right to preside over worship ceremony, appoint Director of ancestral hall and manage the costs of sacrificial affairs, land tax and other levies; the right to dominate the family assets; the right to decide the rights and wrongs of family affairs (specially for some minor criminal cases and common civil cases, the clan leader has the supreme authority in this respect: he handles internal family matters and disputes and maintain family stability and feudal order according to the family rules and in the name of ancestors); the right to punish the family members, which is derived from the right of family business management. The legislative technique of family rules in the Ming and Qing Dynasties had reached a high level and general clauses had complete three elements just like the articles of law, namely: hypothesis, behavior and disposition. 
For the clan members who have violated the family rules, the clan leader is entitled to carry out punishment and he has the right to decide the marriage of family members [4].

2) To adjust the civil relations in the family and maintain the family order

In a family, members have different capacities for civil rights and civil conduct because of their different in the family network. In general, the family elders have full right capacities, and the inferior's legal capacity is severely restricted, women are required to abide by the "Three Obediences And Four Virtues" (in ancient China a woman was required to obey her father before marriage, and her husband during married life and her sons in widowhood, which are called three obediences; fidelity, physical charm, propriety in speech and efficiency in needle work are called four virtues), without independent personality; the family property hosts and family rulers have full right capabilities, and the ordinary family members have limited right capacities. For property, some families separately develop the single regulations related to property, e.g. "Memorial Ceremony for Hu's Tomb Field" in Mingrenhe county and "Record on Public Field" in Dongting Wang's genealogy specified the distribution of family property, management, operation mode and so on. In general, the family property is of one-side sale and purchase, only bought but sold. Because the family property is the foundation of clan existence, and in order to make clan solidarity, the property hard accumulated may not be divided. To maintain the ruling order for grassroots, the state must try to protect the family property ownership. In the laws of Ming and Qing dynasties, it is stipulated that no one is allowed to steal or sell or divide the family property. In marriage, the most prominent content of Family Laws in the Ming and Qing dynasties is the rating marriage. The purpose of marriage is always not involved in the men and women themselves, and as long as the parents of two surnames consent and a certain ceremony is held, the marriage will be established. "Lineal ascendants, especially male lineal ascendants, have absolute right to preside over a marriage”. Even it is stipulated by the state laws that if a marriage engagement is made by man and woman themselves in other place but the ascendant also decides a marriage engagement in the hometown, latter than the former, and as long as the wedding is not held, the former will be invalid, otherwise the man or woman will receive the "punishment of flogging of one hundred or eighty sticks". Family rules also prohibit the marriage between man and woman with the same surname, and interracial marriage not only can guarantee the health of future generations, but also can expand the clan strength. In the Ming and Qing dynasties, a number of noble families emerged in Jiaxing of Zhejiang, where marriage is the most important way to expand their clan strength. Another important marriage provision in the Family Laws of Ming and Qing dynasties is to maintain the authority of husband. The feudal autocratic ideology of females being inferior to males in China for thousands of years did not change with the times, the status of women in a family is just a tool to continue family line, and women must comply with the "Three Obediences And Four Virtues", and if accidentally breaking one of "Seven Out-of-Rules", she will faces the risk of being divorced. For inheritance, the continuity of family line and inheritance of family property are essential for a clan. To ensure the pureness of a clan, no one who is not a member of the clan is allowed to inherit the family estate. Family inheritance in a clan mainly comprises of ancestral inheriting system and property inheritance. The ancestral inheriting system means the succession to title and position, and from ancient times, only one person in a family line has the right of ancestral inheritance. There are two inheritance modes: inheritance and adoption. Inheritance is passed in order of seniority of their lines of descent, namely legitimate firstborn son, legitimate firstborn grandson, legitimate second-born son, illegitimate firstborn son, illegitimate firstborn grandson, illegitimate second-born son and illegitimate second-born grandson. If no son, the adoption of a relative's son as the heir for succession of family line is allowed, unlike the direct descendant, the blood relationship between the inheritor and the deceased is more remote through adoption. The adoption of a relative's son as the heir for succession of family line may require for the prior negotiation with the clan members, and the written covenant of succession shall be signed by the clan members, and the family will perform interference in case of disputes. In respect of property inheritance, system of property divided equally by all sons was adopted by families in the Ming and Qing Dynasties, and females had no right to inherit family property. Since descendants had no independent property right under the guard of their patriarch, property inheritance was immutable, only allowing descendants to inherit the family property of their ancestors, and the elder was not allowed to inherit property of younger generation as it is today.

The family rules play a vital role in maintaining the family order. In Fei Zhengqing's view, Chinese family is a little world of its own, a mini country state, and the unit of the society is not an individual but the family which shall be the responsibility of local politics. Seeing from the social perspective, the people in villages in China are generally organized according to family system and then constitute the neighborhood society in the same area. 
Hence, to keep the internal family in good order is to maintain the region well-guarded. In addition, there shall be adequate provisions on the obligation of loyalty to the country in the family rules for only in this way can it be guaranteed that the clan members would try to avoid violating national laws and maintain the family stability. For these reasons, contents of being law-abiding, being friendly with clan members, not violating national laws, paying taxes and so on are stated in the family rules in general sense. During the traditional Chinese society, the thought "No Lawsuit" was quite prevalent: any dispute would be settled between families or within the clan as far as possible. Qu Tongzu once said that: "Family is the primary judicial organ; the disputes and conflicts within the family group shall be arbitrated by the clan leader while those unsolvable are handled by state judicial organs, which will save judicial officers a lot of trouble and ensure the fairness of result. It's true that not even good officials can settle family troubles. Many disputes can be reconciled without being involved in lawsuits; and some family sins are beyond the scope of laws and can be only handled by the family itself". Moreover, the family rules are also of great importance in defending state domination. Plenty of family rules require the clan members to obey the national laws and fulfill the obligations of paying taxes and taking service, etc. Taxes are an important source of state revenue and also the material guarantee for the normal operation of state apparatus. The clan must urge its members to follow through this basic obligation thereby ensuring them freed from the liability of national laws and maintaining steady development of the clan. As a result, special clause has been set in the clan regulations of different places to require the clan members to perform the duty of paying taxes.

\section{Attitude of State to Family Rules and Clan Regulations}

\subsection{Attitude of Ruling Class to Family Rules and Clan Regulations}

The State's attitude to family rules and clan regulations depends on the state's attitude to families. In the period of Two Song Dynasties after the Han Dynasty, the clan community was as a kind of folk spontaneous blood organization. Developing under the "reconstruction clan" call of Neo Confucians, the relationship between the state and the clan gradually eased; the ruler of the state acquiesced in family owning limited family rules for autonomy. During the Ming and Qing Dynasties, the relationship between the state power and the clan organization developed up and down, which determined that state's attitude were inconsistent to family rules; but generally the state adopted the policy of both support and suppression. Ming Taizu Zhu Yuanzhang and his civilian officials and military officers were mostly from plain folks of humble origin. They knew the role of clan organizations at the grassroots level very well, so they emphasized clan organizations in the political life and also gave some support for the family rules. In the $30^{\text {th }}$ year of the Early Qing Dynasty, the imperial court adopted the policy of suppression and crackdown on clan, so that the local clans were difficult to accept the court in the Early Qing Dynasty emotionally, even contended against the court, as a result, the clans became the keynote target cracked down by the court. However, in the late period under the reign of Emperor Shunzhi and in the period under the reign of Emperor Yongzheng, the imperial court became firm and steady, and the contradictions gradually eased. In order to win over the local forces, the imperial court began to have great tolerance for the family, and support the implementation of family rules. From the view of the ruling class, the imperial court of Qing Dynasty had to blend the culture of Manchu and Han to adapt to feudal culture with a long history for the sake of a steady and firm domination. The imperial court recognized the popularity of clan organization in the grass-roots society and the ingrained status of clan consciousness in the majority of farmers as well as the role of clan organization in the economic, social, political and social life. Therefore, the supreme ruler extended a hand of co-operation to the clan and implemented a series of policies, in between the state power and the clan forming a harmonious cooperation relationship. As the superstructure, the state law and family rules coexisted and helped mutually. In the period under the reign of Qianlong Emperor, a variety of social contradictions became sharply, and the court adopted the policy of suppression plus support. With the support for the clan in earlier stage, the local clan forces developed rapidly but they went too far. In the process of clan autonomy, it exposed the unadapted aspect of clan autonomy inharmonious with the court and the state law, to the extent that, the rulers had to adjust their attitude. First, the court canceled the clan leader's right to put somebody to death. In order to inhibit the expansion of clan forces, the court implemented "family system" and rectified ancestral halls and temples. However, the court also supported family rules to a certain extent, for example, strictly ordering family to manage unemployed children and prosecuting wicked person and allowing the clan leader to redeem confiscated or stolen ancestral properties. After the Jiaqing period, the state law integrated with family rules further. But with the intensification of social contradictions, the rule of the Qing Dynasty gradually declined and the 
court began to use clan organizations to stabilize grassroots level order. And then the court gradually indulged the family rules and clan regulations as the rights of clan leader once restricted were recovered. Even the court admitted the effect of clan regulations to process clan affairs and restrain clansmen; the common people were not allowed to file a suit directly to the official; the clan could get involved in civil cases accepted by the feudal official at any time and could mediate and withdraw and repeal the case; the court allowed the increase and expansion of the clan.

\subsection{Altitude of Judaical Office of Local State to Family Rules}

In the Ming and Qing Dynasties, the court attached great importance to Xiangyue, Xiangli, Baojia and other organizations for the government of the grassroots society. Many times the family organizations were integrated together with Xiangli autonomy. Proclamation for Education of People, issued in Hongwu period of Ming Dynasty, emphasized "all litigation and small cases, including household service, marriage, land rights and fights, should be judged by the aged of native place and Lijia". At the same time, the court commended the Zheng Family Rules and encouraged clans to establish their own regulations; in this way the Xiangli autonomy are integrated together with autonomy. In the middle and late Ming Dynasty, the family rules and clan regulations mostly gave the clan leader the judicial power within the clan, which made the inner clan judicature the primary defensive line of the state judicature; this phenomenon could be showed through a fact that the clan applied for approval of clan regulations to the government and the government generally approved their application. The local officials supported the inner governance power of clan leaders, which was related to household service levy for the sake of the government. The local official also gave the clan inner punishment right when approving their application for clan regulations and giving the clan leader right, in order to realize the clan's judicial punishment within their clan. In this case, the local officials made it clear to the people that they were the backup force of clan leaders, which backed off people's idea of appeal. In the period under the reign of Daoguang Emperor, Xiangshan Mai's young generations refused to accept the judgment and appealed to the country government. However, the country leader Zhou said "for anyone who dares to disobey clan decision and appeal, the respectable old man could abolish his qualification to get sacrificed meat or even use family punishment or report to the superior. I will punish you strictly without any tolerance”. Some local officials simply threw the responsibility of solving disputes completely to the clan, so that they needn't to do anything. In the late Qing Dynasty, Taiwan Danxin Department issued a decision on an illegal child of Zheng's family: "this man is illegal. He did harm to his family relatives. You are the clan leaders, so you can use your family rules to punish this man and keep a record" [5]. That is to say the inner judicature of the clan became a necessary part of state judicature virtually.

\section{Conclusion}

The family rules and regulations can be said to be "Quasi Laws and Regulations" of Chinese traditional characteristics. We use "quasi" to describe them, because they imitated the national legal organizations and symbol forms. In different extent the use of a mark and efficacy of the law, but does not have the standard mode of national compulsory force [6]-[10]. The Chinese feudal society had two structure systems, "public system" and "private system". The "public" system was the political power of centralized-power autarchy, while the "private" system included "clan power, god power and husband power", namely family power; these systems constituted a very complete solid feudal social structure. Chinese society actually has two sets of operation mechanism; one is legal mechanism with reflection of new value recognized by the state or the law. The other is the etiquette and custom mechanism, consisting of family rules and clan regulations, with reflection of former value maintained by the clan. The legal mechanism is of clear regulation and wide application range, while the clan system depends on the mass's wide recognition and their identity of conscience, emotion and value orientation. During the Ming and Qing Dynasties, the society is in a dual structure; the state power coexisted with the clan community which had political, economic, cultural and other functions. The community had received national recognition, generally speaking, family rules represented powerful group's interests within the family; and the powerful group of the clan belonged to a part of the whole society's ruling class. Therefore, family rules were essentially the same with state law; they both need to maintain social order within the same limit. However as the clan community had the independence and autonomy in certain, there was a certain difference between the clan regulations and state law. The family rules reflected the state law, but in some aspects they were disconnected 
with each other [11] [12]. But no matter how feudal ruler's attitude was to family rules, they played a major role in grassroots level. As two elements of the law in the feudal society, the state law and the family rules from different angles stabilized the feudal relations, maintained the feudal order and together constituted a complete system of feudal law.

\section{References}

[1] Qu, T.Z. (1998) Collection of Qu Tongzu’s Law Papers. China University of Political Science and Law Press, Beijing.

[2] Shigega, S. (2003) Principles of Chinese Family Rules. Law Press, Beijing.

[3] Feng, E. (1994) Evolution of Chinese Social Structure. Henan People’s Publishing House, Zhengzhou.

[4] Wu, S.C. (1996) Chinese Traditional Legal Culture. Peking University Press, Beijing.

[5] Fei, C.K., Ed. (1998) Chinese Family Rules and Clan Regulations. Shanghai Academy of Social Sciences Press, Shanghai.

[6] Zhu, Y. (2002) Hard Course of Chinese Law. Heilongjiang People’s Publishing House, Beijing.

[7] Zhang, J.F. (1997) Tradition and Modern Transformation of Chinese Law. Law Press, Beijing.

[8] Tao, X.S. (1992) Marriage and Family. Shanghai Bookstore Publishing House, Shanghai.

[9] Ma, X.H. (1997) Manners and Law. Economic Management Press, Beijing.

[10] Tanaka, C.C. (1992) Chinese Clan and Drama. Shanghai Ancient Books Publishing House, Shanghai.

[11] Su, Y.G. (2000) Law Code and Regulations of Ming and Qing Dynasties. China University of Political Science and Law Press, Beijing.

[12] Xu, Y.J. (1955) Family System History of Ming and Qing Dynasties. Zhonghua Book Company, Beijing. 
Scientific Research Publishing (SCIRP) is one of the largest Open Access journal publishers. It is currently publishing more than 200 open access, online, peer-reviewed journals covering a wide range of academic disciplines. SCIRP serves the worldwide academic communities and contributes to the progress and application of science with its publication.

Other selected journals from SCIRP are listed as below. Submit your manuscript to us via either submit@scirp.org or Online Submission Portal.
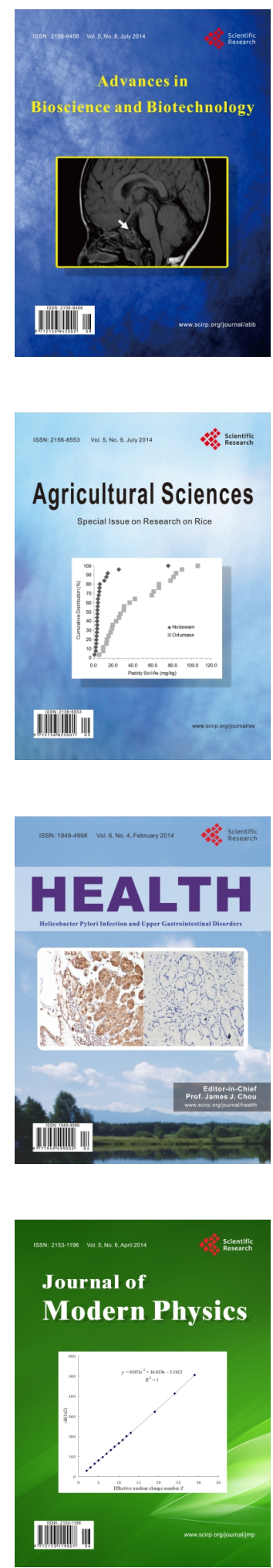
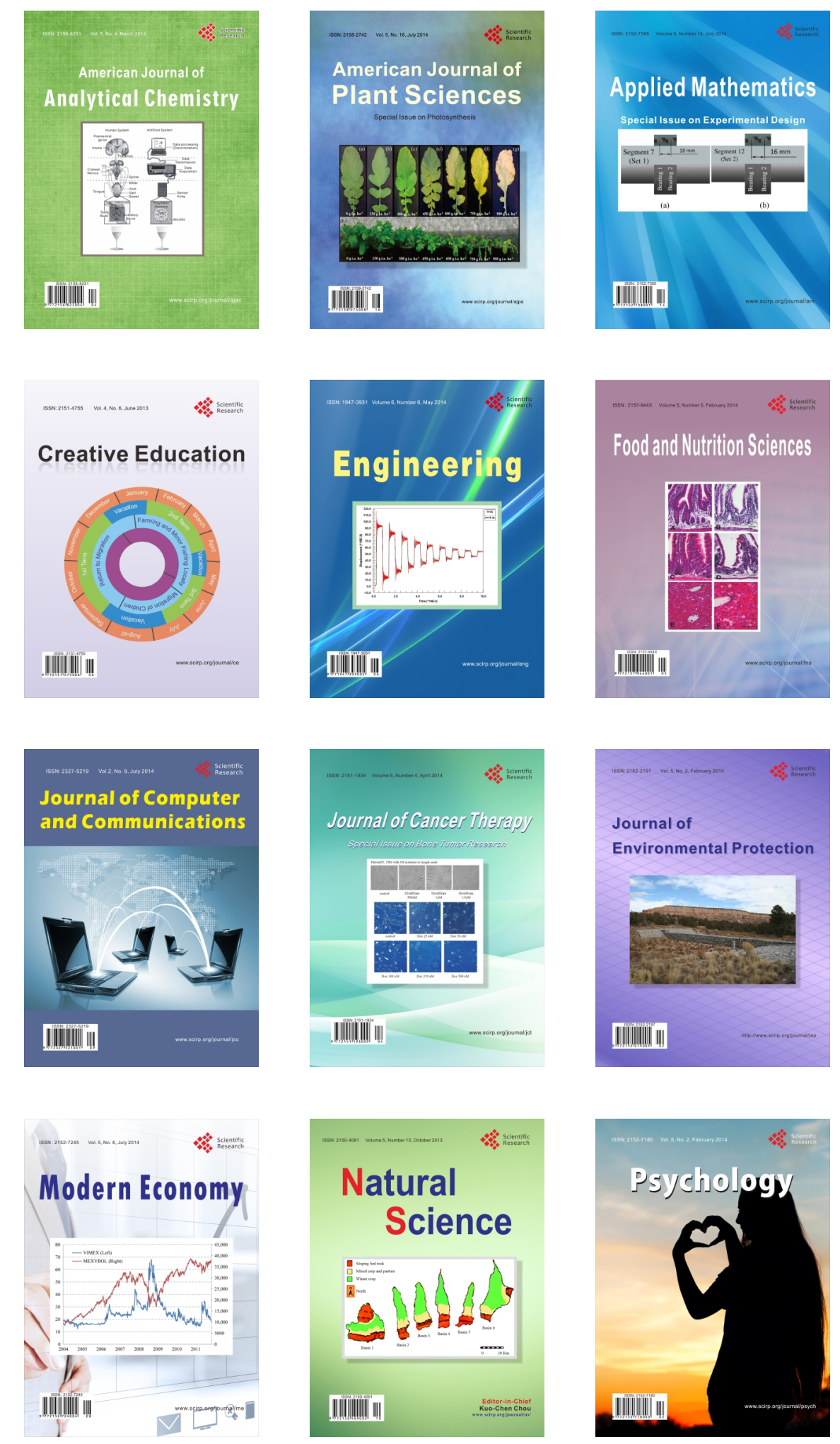